San Jose State University

SJSU ScholarWorks

Master's Theses

Master's Theses and Graduate Research

1990

\title{
High school students' awareness of high blood pressure as a major problem in our society
}

Carol Sadlier

San Jose State University

Follow this and additional works at: https://scholarworks.sjsu.edu/etd_theses

\section{Recommended Citation}

Sadlier, Carol, "High school students' awareness of high blood pressure as a major problem in our society" (1990). Master's Theses. 20.

DOI: https://doi.org/10.31979/etd.ayh9-sd6r

https://scholarworks.sjsu.edu/etd_theses/20

This Thesis is brought to you for free and open access by the Master's Theses and Graduate Research at SJSU ScholarWorks. It has been accepted for inclusion in Master's Theses by an authorized administrator of SJSU ScholarWorks. For more information, please contact scholarworks@sjsu.edu. 


\section{INFORMATION TO USERS}

The most advanced technology has been used to photograph and reproduce this manuscript from the microfilm master. UMI films the text directly from the original or copy submitted. Thus, some thesis and dissertation copies are in typewriter face, while others may be from any type of computer printer.

The quality of this reproduction is dependent upon the quality of the copy submitted. Broken or indistinct print, colored or poor quality illustrations and photographs, print bleedthrough, substandard margins, and improper alignment can adversely affect reproduction.

In the unlikely event that the author did not send UMI a complete manuscript and there are missing pages, these will be noted. Also, if unauthorized copyright material had to be removed, a note will indicate the deletion.

Oversize materials (e.g., maps, drawings, charts) are reproduced by sectioning the original, beginning at the upper left-hand corner and continuing from left to right in equal sections with small overlaps. Each original is also photographed in one exposure and is included in reduced form at the back of the book.

Photographs included in the original manuscript have been reproduced xerographically in this copy. Higher quality $6 "$ " $\times 9$ " black and white photographic prints are available for any photographs or illustrations appearing in this copy for an additional charge. Contact UMI directly to order.

\section{$\mathrm{U} \cdot \mathrm{M} \cdot \mathrm{I}$}

University Microtilms International A Bell \& Howell Information Company 300 North Zeeb Road. Ann Arbor. MI 48106-1345 USA

$313 / 761.4700 \quad 800 / 521-0600$ 

Order Number 1841697

High school students' awareness of high blood pressure as a major health problem in our society

\section{Sadlier, Carol, M.S.}

San Jose State University, 1990 

HIGH SCHOOL STUDENTS' AWARENESS OF

HIGH BLOOD PRESSURE AS A MAJOR HEALTH PROBLEM IN OUR SOCIETY

\author{
A Thesis \\ Presented to \\ The Faculty of the Department of Nursing \\ San Jose State University
}

In Partial Fulfillment

of the Requirement for the Degree

Master of Science

By

Carol Sadier

August 1990 
APPROVED FOR THE DEPARTMENT OF NURSING
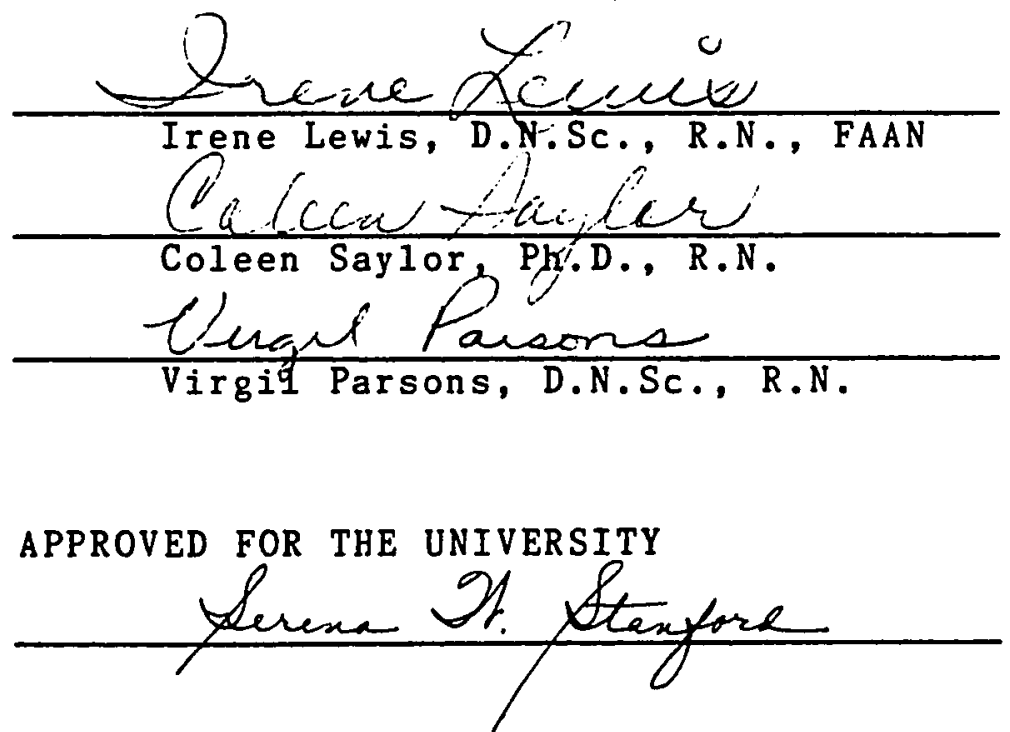


\section{ACKNOWLEDGEMENTS}

I would like to acknowledge those who gave me the support and encouragement to complete this thesis. Many thanks to my thesis reader, Dr. Irene Lewis, for staying with me for so many years. Thanks to my husband, John, and daughters, Carissa, Alison, and Elizabeth for their continual patience and support. Thanks to my parents for their encouragement and my brothers, sister, and friends for always showing an interest by asking how I was doing. A special thank you to my Aunt and Uncle, Marian and John Everett, for helping me with the editing. Finally, I need to thank God for helping me so this day has finally been realized. 


\section{ABSTRACT}

THE HIGH SCHOOL STUDENTS AWARENESS OF HIGH BLOOD PRESSURE AS A MAJOR HEALTH PROBLEM IN SOCIETY

By Carol Jean Sadiier

The purpose of the study was to determine the level of awareness of high blood pressure as a major health problem in our society for: (a) those high school students who are members of the varied ethnic groups, and (b) those students whose family members have a history of hypertension, stroke, or heart disease.

The study utilized secondary data analysis. The sample consisted of 347 questionnaires filled out by high school students during a Santa Clara County American Heart Association blood pressure screening program. Descriptive statistics of the data revealed that $79 \%$ of the students from the various ethnic groups were aware that high blood pressure is a major health problem. The percentage of students who were aware of high blood pressure as a major health problem who have family members with a history of high blood pressure is $63 \%$, stroke is $23 \%$, and heart disease is $14 \%$. 


\section{TABLE OF CONTENTS}

Page

LIST OF TABLES...........................

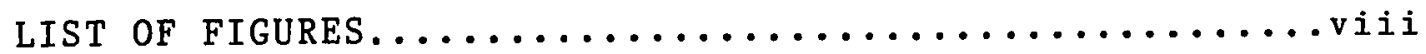

\section{Chapter}

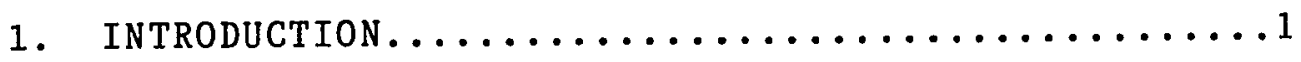

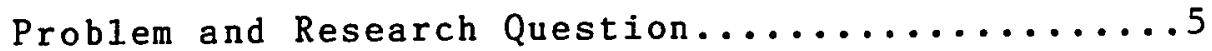

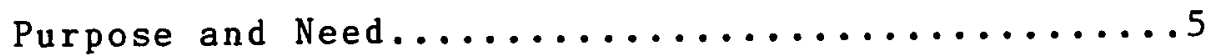

Definition of Terms.....................

Setting and Sample Population..............

Research Design and Methodology.............

Scope and Limitations.................

2. CONCEPTUAL FRAMEWORK AND RELATED LITERATURE......99

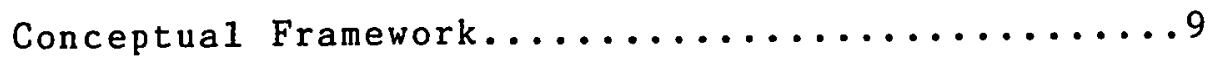

Related Literature......................

Summary .......................... 18

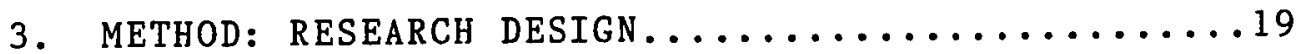

Sample and Setting.....................

Data Collection Instrument.................

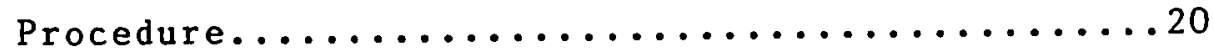

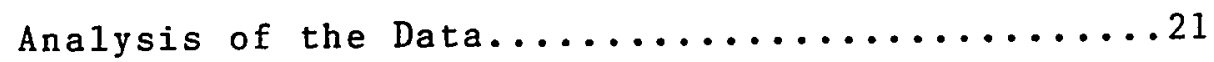

4. ANALYSIS AND INTERPRETATION OF DATA.......... 23

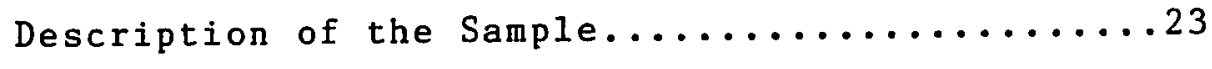

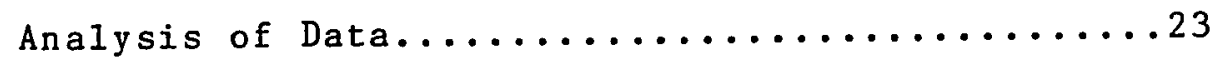


5. CONCLUSIONS AND RECOMMENDATIONS........................

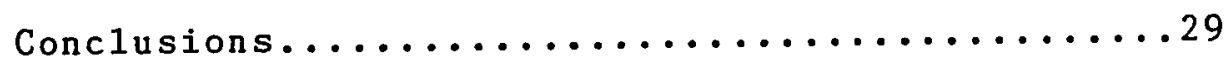

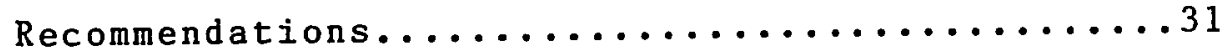

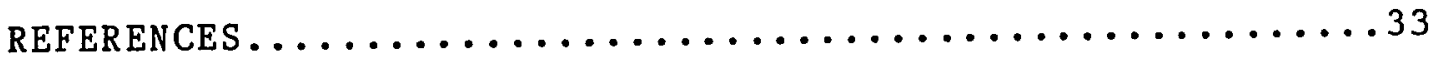

APPENDIXES

A. Blood Pressure Standards for Children......42

B. Questionnaire.................... 45

C. Consent Letter................... 47

D. Committee for the Protection

of Human Subjects................49 


\section{LIST OF TABLES}

Table

Page

1. The Level of Awareness of High Blood Pressure as a Health Problem by High School Students

from Various Ethnic Groups...............24

2. The Level of Awareness of High Blood Pressure as a Health Problem by High School Students Who Have or Have Had a Family Member with either High Blood Pressure, Stroke, or Heart

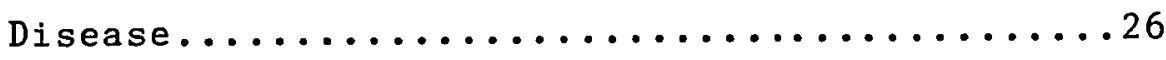

3. The Level of Awareness of High Blood Pressure as a Health Problem by High School Students from the Various Ethnic Groups Who Have or Have Had a Family Member with either High B1ood Pressure, Stroke, or Heart Disease.....27 


\section{LIST OF FIGURES}

Figure

Page

1. Age-specific percentiles of BP measurements in boys-13 to 18 years of age; Korotkoff

phase $V(K 5)$ used for diastolic BP...............

2. Age-specific percentiles of $B P$ measurements in girls-13 to 18 years of age; Korotkoff

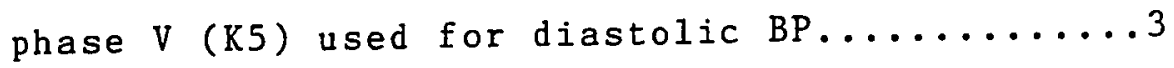

3. Age-specific percentiles of $B P$ measurements in boys-birth to 12 months of age; Korotkoff phase IV (K4) used for diastolic BP.........4

4. Age-specific percentiles of BP measurements in girls-birth to 12 months of age; Korotkoff phase IV (K4) used for diastolic BP.........41

5. Age-specific percentiles of BP measurements in boys-1 to 13 years of age; Korotkoff phase IV (K4) used for diastolic BP..........

6. Age-specific percentiles of $B P$ measurements in girls-1 to 13 years of age; Korotkoff phase IV (K4) used for diastolic BP........41 
Chapter 1

INTRODUCTION

Hypertensive disease "is a mass public health problem in the United States." It is responsible for the "premature sickness, disability, and death" of a large population of Americans. Hypertension "is widely prevalent among al1 strata of the adult population" and in every geographic location in the United States (Stamler, 1973, p. 11).

Although volumes of literature have been written about adult hypertension, only recently has research included hypertension in children and adolescents. These newer studies support the concept that hypertension in the adult may have had its origin during childhood (Burke, Freedman, Webber, \& Berenson, 1986; Task Force Members, 1987; World Health Organization Study Group, 1985).

Although this study examined hypertension in children, to provide a more meaningful context for the data, relevant information on adult hypertension will also be discussed.

Current statistics reported by the American Heart Association (AHA) (1989) indicate that 60,130,000 American children and adults are afflicted with high blood pressure. In $90 \%$ of this hypertensive population, the cause is unknown. For the adult, the disease represents one of the major risk factors in heart attacks and strokes, which, along with cancer, are the three leading causes of death 
in the United States.

In the child and adolescent, the rise of blood pressure with age and the development of hypertension represents an interaction between genetic and environmental factors. Although hypertension seems to aggregate in families, what the specific genetic factors are which determine the normotensive from the hypertensive state has not yet been found (Loggie et a1., 1984; Burns \& Lauer, 1987, pp. 305-313).

In 1977 and again in 1987, the National Heart, Lung, and Blood Institute (NHLBI) appointed a Task Force on Blood Pressure Control in Children. The Task Force Members (1977, 1987) believed it essential to identify the prehypertensive state in the early developmental years in order to determine the children at long-term risk.

The 1987 Task Force Members revised the earlier blood pressure standards for children (see Appendix A). The revision for adolescents is shown in Figures 1 and 2 (see p. 3). The revision is as follows:

High normal BP is defined as average systolic and/or diastolic BP between the 90 th and 95 th percentiles for age and sex; high BP or hypertension is defined as average systolic and/or diastolic BP equal to or greater than the 95 th percentile for age and sex on at least three occasions. ( $p .5$ ) 

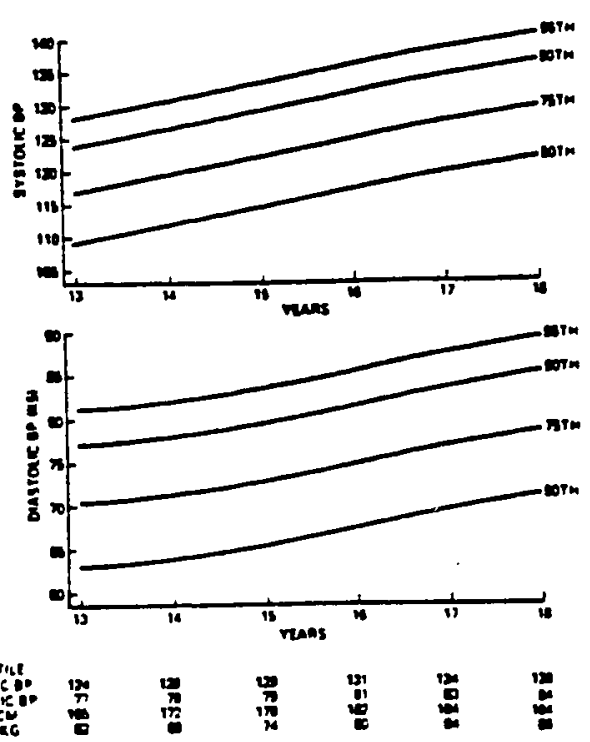

Figure 1. Age-specific percentiles of $\mathrm{BP}$ measurements in boys13 to 18 years of age; Korotkoff phase V (K5) used for diastolic BP.
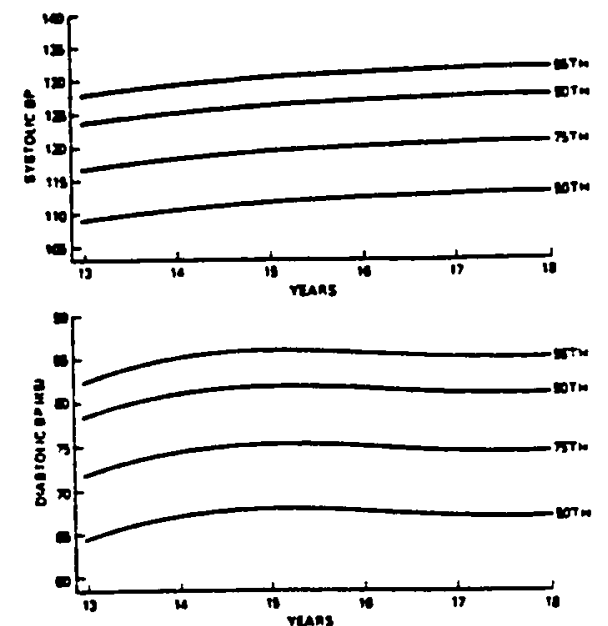
算

Figure 2. Age-specific percentiles of $B P$ measurements in girls13 to 18 years of age; Korotkoff phase V (K5) used for diastolic BP.

Note. From "Report of the Second Task Force on Blood Pressure Control in Children-1987" by Task Force Members, 1987. Pediatrics, 79, p. 5. Copyright 1987 by Pediatrics. Reproduced by permission of Pediatrics. 
The Task Force further emphasized: "If the BP reading is high normal for age, but can be accounted for by excess height for age or excess lean body mass for age, such children are considered to have normal BP" (p.7). These new standards are considered to be the main reference source for blood pressures in children (Mollohan, 1986; Sinaiko, Gomez-Marin, \& Prineas, 1989).

Tochikubo, Sasaki, Umemura, and Kaneko (1986) and Burns and Lauer (1987, p. 312) stress the importance of prevention and reduction of high blood pressure through the education of today's children. The education needed to reduce the risk factors that predispose to hypertension can be accomplished through health professionals, teachers, family, or other groups in the community. The WHO Study Group (1985) believes:

The prevention of high blood pressure in childhood and adolescence is, above all, aimed at the prevention of hypertension later in life. Preventive measures begun in adulthood are also a part of the strategy of prevention, but the chances are that the earlier prevention starts, the more likely it is to be effective. Moreover, the habits that are related to an undue rise in blood pressure with age are formed early and become increasingly difficult to change later in life. (p. 25) 
The paradigm of awareness discussed by the medical sociologists, Barney G. Glaser and Anselm L. Strauss (1964), will be utilized as the conceptual framework for this study. The paradigm consists of four foci which deal with interaction. Awareness was utilized in the study of Blacks and other minorities by Irene Lewis (1980). Findings showed that hypertensive individuals who had friends or family members who had experienced a stroke or heart attack had an increased awareness of the consequences of hypertension.

Problem and Research Question

Prevention and reduction of high blood pressure in adulthood is seen by modern authors as a process that needs to begin in childhood and adolescence. Education of our youth about risk factors that contribute to the prehypertensive state is seen as the primary defense against hypertension later in 1ife. Therefore, the research question asked the high school student from varied ethnic groups with varied family medical histories what level of awareness he or she had of high blood pressure as a major health problem in our society.

Purpose and Need

The purpose of this study was to determine the level of awareness of high blood pressure as a major health problem in our society for: (a) those high school students 
who are members of varied ethnic groups, and (b) those students whose family members have or have had either hypertension, stroke, or heart disease. The need to study this subject area has become apparent by the growing concern of health professionals, who realized the "evidence of high blood pressure can be found at an early age in some of those who subsequently develop its full blown manifestations" (AHA, 1982, p. 1).

$$
\text { Definition of Terms }
$$

For the purpose of this study, the following definitions apply:

1. Adolescence refers to ages 13 through 18 who are enrolled in high school.

2. Awareness is the combination of: (a) present experiences, (b) perception of previous experiences stored in memory, and (c) prior memory related to experiences from one's own personal involvement or from the publicized experience of others (Klatzky, 1984, pp. 3-4).

3. Blood Pressure is the force the blood exerts against artery walls, hence the pressure within the arteries (AHA, 1988, p. 25).

4. Childhood refers to ages 1 through 12 .

5. Heart attack (Myocardial Infarction) is the damage or death to a section of heart muscle caused from an insufficient blood supply to the area (AHA, 1988, p. 26). 
6. High blood pressure (Hypertension) in the child or adolescent is the "average systolic and/or diastolic BP equal to or greater than the 95 th percentile for age and sex on at least three occasions" (Task Force Members, 1987, p. 5).

7. Stroke (Cerebral Vascular Accident) is an inadequate blood supply to part of the brain (AHA, 1987, p. 31 ).

Setting and Sample Population

This study was based upon data collected by the Santa Clara County American Heart Association (SCCAHA) in the Spring of 1984. Therefore, it is secondary analysis of those data. The SCCAHA administers an annual blood pressure screening program in a local high school. Approximately 30 students enrolled each year in physiology are trained to take blood pressures. Of the 1552 students enrolled in the high school in 1984, 580 participated in the blood pressure screening and completed the SCCAHA questionnaire (see Appendix B). The subjects were predominantly middle class and represented a composite of the White, Asian, Hispanic, Native American, and Black ethnic groups.

The criteria used by the SCCAHA to include subjects for the sample population were their attendance in school, and their willingness to fill out the SCCAHA questionnaire 
(see Appendix B). The questionnaire was completed after the student's blood pressure had been measured by a high school classmate, certified as an AHA blood pressure screener.

Research Design and Methodology

A retrospective secondary data analysis was used for this descriptive study (Polit \& Hungler, 1983, pp. 174-175, 211-214). The data were collected by the SCCAHA and analyzed with basic descriptive statistics. The tool used was the SCCAHA questionnaire (see Appendix B). The sample consisted of 580 high school students who had their blood pressure measured before they completed the questionnaire. This study assessed their level of awareness of high blood pressure as a major health problem in our society.

Scope and Limitations

Scope for secondary data analysis is limited by the original researcher's sample criteria and the questions asked. The sample is limited to a non-random group of adolescents; therefore, generalizations to other groups are not appropriate. 


\section{Chapter 2}

\section{CONCEPTUAL FRAMEWORK AND RELATED LITERATURE}

Conceptual Framework

Awareness is a paradigm that is key to the study of interaction according to medical sociologists, Barney G. Glaser and Anselm L. Strauss (1964, p. 670). This paradigm serves as the framework for this study. It may involve interaction between (a) two persons, (b) one person and a group, or (c) two groups. For this study, the interaction is between one person and a group. The awareness paradigm according to Glaser and Strauss (1964) is "the total combination of what each interactant in a situation knows about the identity of the other and his own identity in the eyes of the other" (p. 670).

The awareness paradigm has four major foci: (a) open awareness, (b) closed awareness, (c) suspicion awareness, and (d) pretense awareness. It also has certain structural conditions which are elements of social structural units. These units may be a role, status, relationship, community, or even society. As interaction continues, it can change from one type of awareness to another. This focus on interaction is developmental and not static. Interactants maneuver changes in awareness by utilizing various tactics such as facial gestures, indirect phrasing of words, avoiding the other interactant, or by not saying 
anything.

A discussion of the four foci of the awareness paradigm (Glaser \& Strauss, 1964, p. 670) follows with examples from Glaser and Strauss's Awareness of Dying (1984, pp. 29-106). The first focus, open awareness, is when everyone is aware of the identity of the other interactant as well as the other's understanding of his own identity. Open awareness refers to the free communication between hospital staff and the dying patient regarding his or her impending death. The second focus, closed awareness, is when a interactant is not aware of the other interactant's identity or the other's understanding of his identity. This is the dying patient who is unaware of his or her impending death, although the hospital staff is aware. This type of awareness can change to suspicion or open awareness. The third focus, suspicion awareness, is similar to closed awareness, but with modifications. The real identity of one interactant is suspected by the other interactant or the other's understanding of his own identity. This patient is not certain but suspects that the hospital staff believes he is dying. The staff is not aware of the patient's suspicions. Pretense awareness, the fourth focus, is similar to open awareness, but with modifications. The interactants are aware of each other's identity, but act 
otherwise. The patient and hospital staff are both aware of the patient's impending death, but nothing is open $1 y$ said.

For this study, the structural conditions that the students enter into as part of the awareness framework are: (a) open awareness which refers to the high school student who is aware that high blood pressure is a major health problem; (b) closed awareness which refers to the student who is unaware of the medical consequences of high blood pressure and therefore believes it is not a health problem; (c) suspicion awareness which refers to the student who is not certain if high blood pressure is a major health problem, but suspects it might be; and (d) pretense awareness which refers to the student who knows that high blood pressure is a major health problem with major medical consequences, but does not acknowledge these facts. Interaction changes from pretense, suspicion, or closed awareness to open awareness by educating the student about high blood pressure and its status as a major health problem. The student manages the changes of awareness when allowed to absorb the filtering down of knowledge from family, friends, and community members about high blood pressure and its life threatening implications.

The awareness paradigm and its relation to the high 
school student's awareness of high blood pressure as a major health problem will be addressed further in this study .

\section{Related Literature}

The review of the related literature was based solely on medical frameworks as only minimal material was found dealing with both awareness and hypertension. In spite of the prevalence of hypertension "in the United States for many decades," it was not until the 1960 s that "its importance as a public health problem" was recognized (Dannenberg, Drizd, Horan, Haynes, \& Leaverton, 1987, p. 226). It was in 1960 that the Veterans Administration Cooperative Study Group published the first large-scale, long-term, double-blind assessment of antihypertensive drug therapy. Several smaller, short term studies had been reported in the 1950 s by Dorsett, Woods, White, Smith, and Hill (1958), Freis (1959), and Lee, Seligmann, Goebel, Fulton, and Clark (1956). Further reports on antihypertensive drug studies by the Veterans Administration Cooperative Study Group were published in 1962, 1967 , and 1970. These studies showed the benefit of drug therapy in the prevention of strokes and heart disease by bringing the blood pressure within normal range.

One of the earliest organizations, founded in 1924 with the primary purpose of preventing heart disease, 
is the American Heart Association (AHA). Its journal, Hypertension, started in 1979 , is devoted to hypertension research and the sharing of new knowledge (Dustan, 1982). Another high blood pressure prevention program in the United States is the National High Blood Pressure Education Program (NHBPEP) established in 1972 by the National Heart, Lung, and $B l o o d$ Institute (NHLBI). Its first report by the Joint National Committee on Detection, Evaluation, and Treatment of High Blood Pressure was published in 1977, with follow-up reports in 1980, 1984, and 1988. The Task Force Members on the Blood Pressure Control in Children published its first report in 1977 , with an updated report in 1987.

Since high blood pressure is usually asymptomatic, it can be detected only with an instrument. The World Health Organization (WHO) Expert Committee (1978), an agency of the United Nations with responsibility for public health and international health concerns, established the standards for adult borderline hypertension as a persistent elevation of systolic pressure above $140 \mathrm{~mm}$ $\mathrm{Hg}$ or diastolic pressure above $90 \mathrm{~mm} \mathrm{Hg}$. These same levels were used by the $\mathrm{AHA}$ in 1985 as their new threshold for hypertension. Previous figures by the AHA were 160/95 $\mathrm{mg} \mathrm{Hg}$ and above. The revision was made because "statistics have shown that people with blood pressure readings of 
$140 / 90 \mathrm{~mm} \mathrm{Hg}$ and above are at increased risk of disease or premature death from high blood pressure" (p. 4).

The levels of $140 / 90 \mathrm{~mm} \mathrm{Hg}$ are the same as the recommendations of the 1984 and 1988 Joint National Committee on Detection, Evaluation, and Treatment of High

\section{Blood Pressure.}

The blood pressure levels for children and adolescents were established in 1987 by the Report of the Second Task Force on Blood Pressure Control in Children. Hypertension is the "average systolic and/or diastolic BP equal to or greater than the 95 th percentile for age and sex on at least three occasions" (Task Force Members, 1987, p. 5). In the past two decades, there have been many mass blood pressure screening programs of adolescents. Shear, Freedman, Burke, Harsha, and Berenson (1987), in the Bogalusa Heart Study of 3,784 persons aged 5 to 24 , found that hypertension and the central body fat relationship exists in children just as in adults. The authors believe that efforts should continue in the "early identification and prevention of obesity in children" (p. 236). Lynds, Seyler, and Morgan (1980) screened blood pressures of 1,692 Black elementary school children in North Carolina. Their findings showed girls and boys with elevated systolic and diastolic blood pressures "were three times as likely to be obese as black children in the total population" 
(p. 171). Tochikubo, Sasaki, Umemura, and Kaneko's (1986)

blood pressure screening of 6,589 high school students found "obesity and excessive salt intake seem to be major risk factors in juvenile hypertension" (p. 1169). They stressed the elimination or reduction of environmental influences early in life as an important part of hypertension control.

The Muscatine Study by Rames, Clarke, Connor, Reiter, and Lauer (1978) of 6,622 White school children found that blood pressure screening "can identify a large number of school children with blood pressures that are elevated" (p. 250). However, on repeat measurement, few children had sustained elevation. Of those that were elevated, many were obese. Blood pressure screening in St. Lou is of students 14 to 18 years of age by Goldring et al. (1977) indicated that "blood pressure and weight were significantly related" ( $p$. 888). They also found mean blood pressures of White male children to be significantly higher than Black males and the mean blood pressures of White females the same or higher. The finding of no racial differences was also seen in the screening of 710 Black and 620 White male children, and 585 Black and 566 White female children, aged three to 14 years in St. Louis by Londe, Gollub, and Goldring (1977). No differences in blood pressure readings among Black, Mexican-American, 
or White children were noted by Horan and Sinaiko (1987)

in their Synopsis of the Report of the Second Task Force

on Blood Pressure Control in Children, or by Baron, Freyer, and Fixler (1986) in their study of 10,641 eighth grade students in Dallas, Texas. These findings are contrary to the AHA statistics, which in 1987, 1988, 1989 indicated that Black Americans had a $33 \%$ greater chance of developing high blood pressure than Whites. Stamler, Stamler, Riedlinger, Algera, and Roberts (1976), in their screening of one million Americans from 1973 through 1975, found higher systolic pressures in Blacks than in Whites, except in Black men 20 to 29 years of age. "Mean DBPs were higher for black than for whites" according to Stamler et al. (1976, p. 2302).

Excess body weight and a positive family history of hypertension predispose to high blood pressure in both White and Black children and adults according to Prineas, and Gillum (1985, p. 31). Falkner (1986) and the AHA (1987) also recognized obesity and family history as contributing factors in children and adolescents. Stamler, Stamler, Riedlinger, Algera, and Roberts (1979) found "rates of hypertension at screening in those with positive family history were approximately twice as high as for those with negative history" (p. 44). The Joint National Committee on Detection, Evaluation, and Treatment of High 
Blood Pressure (1984) agreed that children with

hypertensive parents are at increased risk of developing high blood pressure.

Fixler and Laird (1983) believe that mass blood pressure screening of children should not be done. The low prevalence of sustained elevation in their screening of 10,641 Black, White, and Latin-American eighth grade students in Dallas, and the repeat blood pressure screening of these students 2 and 4 years later, led the authors to believe "there is potential for psychological damage by misclassifying a child as hypertensive" ( .463$)$. They recommend blood pressures be routinely measured in the physician's office, where the physician can explain to the parents the pressure reading and its significance. The 1977 Members of the Task Force on Blood Pressure Control in Children recommend that no mass blood pressure screening of children occur. Instead, they suggest that hypertension detection be included in the total health care of the child. Children who are at "high risk of developing elevated blood pressure should be evaluated for other atherosclerotic risk factors and should be taught to observe necessary hygienic measures for lowering risk factors" (p. 799). Avoiding the excess intake of salt and controlling weight seem to be the first steps in preventing hypertension in those who at an early age have 
been identified to be at increased risk. Predicting who will later develop hypertension appears to be determined by its existence in the parents or by blood pressure levels in childhood or adolescence (Task Force Members, 1977).

\section{Summary}

The review of the related literature depicts the existence of controversy about conducting mass blood pressure screening of children. This study explored mass blood pressure screening of adolescents in an attempt to add to the body of knowledge.

The related literature has indicated that certain children and adolescents can be shown to be at increased risk of developing hypertension in adulthood. Factors that seem to weigh heavily in the later development of hypertension are individuals of the Black ethnic group and/or those who have a positive family history. Other factors, such as obesity, excessive salt intake, and elevated blood pressure reading in childhood or adolescence, also play a part in the later development of hypertension. Moving along the path from closed awareness to open awareness of high blood pressure as a major health problem and its medical consequences, stroke and heart disease, appears to be a major factor in the prevention of hypertension in adulthood. 
Chapter 3

METHOD : RESEARCH DESIGN

Students voluntarily completed a Santa Clara County American Heart Association (SCCAHA) questionnaire (see Appendix B) after their blood pressure had been measured by a high school student, certified as an American Heart Association (AHA) blood pressure screener. The data were collected in the Spring of 1984 by a SCCAHA health professional. Secondary analysis research was done on the collected data. The study was retrospective and descriptive.

Sample and Setting

The sample consisted of students in a Santa Clara County Public High School, grades 9 through 12. They lived in the same school district, but were from different socioeconomic and cultural backgrounds. They were predominantly middle class and represented a composite of the White, Asian, Hispanic, Native American, and Black ethnic groups. The criteria used to include subjects in the sample population were their attendance in school and their willingness to complete the SCCAHA questionnaire ( see Appendix B).

Five hundred and eighty students participated in the program. The total enrollment of the school at the time was 1522 students. 
Data Collection Instrument

The data collection instrument was a questionnaire (see Appendix B) designed by the SCCAHA. It consisted of 15 questions plus the date. The first three questions asked the student for his or her age, class period, and year in school. Question number 4 asked for ethnic group, and number 6 asked if anyone in the family has or has had (a) high blood pressure, (b) stroke, or (c) heart disease. Question number 13 allowed for recording the systolic and diastolic blood pressure reading. Question number 15 asked the student his or her belief of high blood pressure as a significant health problem. The choices were: (a) no significance, (b) a minor problem, or (c) a major problem.

Permission to review the data from the questionnaire was received from the SCCAHA (see Appendix C). Institutional Review Board approval was obtained through the Committee for the Protection of Human Subjects at San Jose State University, San Jose, California (see Appendix D).

\section{Procedure}

Annually and up to the present, the SCCAHA has been administering a blood pressure screening program in a local public high school. Approximately 30 students enrolled in physiology are trained to take blood pressures. 
These students are predominantly 12 th graders who plan to continue their education in college. The blood pressure training is provided by a health professional. It consists of 5 days of lecture and discussion followed by repeated demonstration and practice. The sixth and seventh days are devoted to a paper and pencil test and a return demonstration for correctly taking blood pressures. Those students who pass the written and return demonstration test become certified as AHA blood pressure screeners. On the eighth day of the program, the trained screeners spend the entire day measuring the blood pressure of a large segment of the student body.

After measuring a student's blood pressure, the screener asks him or her to voluntarily complete the SCCAHA questionnaire (see Appendix B). No names are placed on the questionnaire; instead, a code number is given.

Analysis of the Data

The data from 580 questionnaires (see Appendix B) were analyzed with descriptive statistics. Frequencies and percentages were utilized in table format for question 4 (ethnic group), and question 15 (What significance do you think high blood pressure has as a health problem?). Table format was also used for question 6 (Does anyone in your family have or have had the following: (a) high blood pressure, (b) stroke, or (c) heart disease?), and 
question 15. Of the original 580 questionnaires, only 347 could be utilized in the data analysis. Two hundred and thirty-three questionnaires were too incomplete. In particular, they failed to respond to question 15 , or they did not respond to the ethnic identity item. Analysis of the data with the questions in table format is shown in Chapter 4. 


\section{Chapter 4}

\section{ANALYSIS AND INTERPRETATION OF DATA}

This study examined the level of awareness the high school student has of high blood pressure as a major health problem in our society. It looked at students from varied ethnic groups and varied family medical histories.

Description of the Sample

Five hundred and eighty questionnaires (see Appendix B) were completed by high school students in grades 9 through 12. Two hundred and thirty-three of the questionnaires were eliminated from the data analysis as no answer had been given to question 15 (What significance do you think high blood pressure has as a health problem?), or question 4 (ethnic group). Therefore, 347 questionnaires were utilized for the final data analysis.

$$
\text { Analysis of Data }
$$

The results of the 347 questionnaires are shown in Table 1. The table shows the level of awareness the students from various ethnic groups have of high blood pressure as a health problem. The ethnic groups were: (a) Asian, which included Pacific Islanders, Filipinos, and Orientals; (b) Black; (c) Hispanic, which included Chicanos, Mexican-Americans, and other Hispanics; (d) Native American, which included American Indians and Eskimos; and (e) White. In 4 of the 5 ethnic groups, 
Table 1

The Level of Awareness of High Blood Pressure (HBP) as a

Health Problem (HP) by High School Students from Various

Ethnic Groups $(N=347)$

\begin{tabular}{|c|c|c|c|c|c|c|}
\hline \multirow[b]{2}{*}{$\begin{array}{c}\text { Students } \\
\text { from } \\
\text { Ethnic Groups }\end{array}$} & \multicolumn{2}{|c|}{ Major HP } & \multicolumn{2}{|c|}{ Minor HP } & \multicolumn{2}{|c|}{ No HP } \\
\hline & （ㅍ & $274)$ & ( $\underline{\underline{n}}$ & $\begin{array}{l}57) \\
5 \%\end{array}$ & ( $\underline{\mathrm{n}}$ & 16) \\
\hline & $\underline{\mathrm{n}}$ & $\%$ & $\underline{\mathrm{n}}$ & $\%$ & $\underline{\mathrm{n}}$ & $\%$ \\
\hline $\begin{array}{l}\text { Asian } \\
(\underline{\mathrm{n}}=113)\end{array}$ & 87 & $77 \%$ & 16 & $14 \%$ & 10 & $9 \%$ \\
\hline $\begin{array}{l}\text { Black } \\
(\underline{\mathrm{n}}=33)\end{array}$ & 30 & $91 \%$ & 3 & $9 \%$ & 0 & $0 \%$ \\
\hline $\begin{array}{l}\text { Hispanic } \\
(\underline{\mathrm{n}}=111)\end{array}$ & 88 & $79 \%$ & 21 & $19 \%$ & 2 & $2 \%$ \\
\hline $\begin{array}{c}\text { Native Am } \\
(\underline{\mathrm{n}}=5)\end{array}$ & 2 & $40 \%$ & 2 & $40 \%$ & 1 & $20 \%$ \\
\hline $\begin{array}{l}\text { White } \\
\qquad \underline{\mathrm{n}}=85)\end{array}$ & 67 & $79 \%$ & 15 & $18 \%$ & 3 & $3 \%$ \\
\hline
\end{tabular}


a majority of the respondents $(77 \%$ to $91 \%)$ to the questionnaire indicated they were openly aware that high blood pressure is a major health problem. Forty percent $(\underline{n}=2)$ of the Native American ethnic group $(\underline{\underline{n}}=5)$ were openly aware. The percentage of respondents to the questionnaire who fell into the suspicion awareness category were $9 \%$ to $40 \%$. These individuals were not certain if high blood presssure is a major health problem, and therefore indicated on the questionnaire that it is a minor one. The individuals in the closed awareness category, $0 \%$ to $20 \%$, who were unaware of the medical consequences of high blood pressure indicated on the questionnaire that it is not a health problem.

High blood pressure causes arteries to suffer from an increased strain and the heart has to work harder. This can lead to a stroke or heart disease. Table 2 shows the level of awareness the high school students have of high blood pressure as a health problem, who have or have had a family member with either high blood pressure, stroke, or heart disease.

of the 347 valid questionnaires (see Appendix B) for the study, 157 showed no family members with high blood pressure, stroke, or heart disease; or there was no answer to the question. Since the study was secondary analysis, the true answer of no family member with high blood 
Table 2

The Level of Awareness of High Blood Pressure (HBP) as a Health Problem (HP) by High School Students Who Have or Have Had a Family Member with either High Blood Pressure (HBP), Stroke, or Heart Disease (HT D) $(N=190)$

\begin{tabular}{|c|c|c|c|c|c|c|}
\hline \multirow[b]{2}{*}{$\begin{array}{l}\text { Level of } \\
\text { Awareness of } \\
\text { Students }\end{array}$} & \multicolumn{2}{|c|}{$\underline{\mathrm{HBP}}$} & \multicolumn{2}{|c|}{ Stroke } & \multicolumn{2}{|c|}{ Ht D } \\
\hline & （ & 120) & ( $\underline{\mathrm{n}}$ & $\begin{array}{l}43) \\
3 \%\end{array}$ & ( $\underline{\mathrm{n}}$ & $\begin{array}{l}27) \\
4 \%\end{array}$ \\
\hline & $\underline{\mathrm{n}}$ & $\%$ & $\underline{\mathrm{n}}$ & $\%$ & $\underline{\mathbf{n}}$ & $\%$ \\
\hline Major HP & 92 & $77 \%$ & 30 & $70 \%$ & 21 & $78 \%$ \\
\hline Minor HP & 25 & 21 & 12 & 28 & 5 & 18 \\
\hline No $H P$ & 3 & 2 & 1 & 2 & 1 & 4 \\
\hline
\end{tabular}

Note. 347 valid questionnaires minus 157 with no indication of history of HBP, Stroke, or Ht D $=\underline{N}$ of 190 . 
Table 3

The Level of Awareness of High Blood Pressure (HBP) as a

Health Problem (HP) by High School Students from the

Various Ethnic Groups Who Have or Have Had a Family Member

with either High Blood Pressure (HBP), Stroke, or Heart

Disease $(H t$ D) $(N=190)$

\begin{tabular}{|c|c|c|c|c|c|c|}
\hline \multirow[t]{2}{*}{$\begin{array}{l}\text { Level of Awareness } \\
\text { of Students from } \\
\text { Ethnic Groups }\end{array}$} & \multicolumn{2}{|c|}{$\underline{\mathrm{HBP}}$} & \multicolumn{2}{|c|}{ Stroke } & $\underline{H t} \mathrm{D}$ & $\frac{D}{27)}$ \\
\hline & $\underline{\mathbf{n}}$ & $\%$ & $\underline{\mathbf{n}}$ & $\%$ & $\underline{\underline{n}}$ & $\%$ \\
\hline $\begin{array}{l}\text { Asian } \\
\text { Major HP } \\
\text { Min or HP } \\
\text { No HP }\end{array}$ & $\begin{array}{r}26 \\
5 \\
3\end{array}$ & $\begin{array}{l}76 \% \\
15 \\
9\end{array}$ & $\begin{array}{l}6 \\
1 \\
0\end{array}$ & $\begin{array}{l}86 \% \\
14 \\
0\end{array}$ & $\begin{array}{l}5 \\
0 \\
0\end{array}$ & $\begin{array}{c}100 \% \\
0 \\
0\end{array}$ \\
\hline $\begin{array}{l}\frac{\text { Black }}{\text { Major HP }} \\
\text { Minor HP } \\
\text { No HP }\end{array}$ & $\begin{array}{l}9 \\
1 \\
0\end{array}$ & $\begin{array}{l}90 \% \\
10 \\
0\end{array}$ & $\begin{array}{l}2 \\
0 \\
0\end{array}$ & $\begin{array}{c}100 \% \\
0 \\
0\end{array}$ & $\begin{array}{l}1 \\
0 \\
0\end{array}$ & $\begin{array}{c}100 \% \\
0 \\
0\end{array}$ \\
\hline $\begin{array}{l}\frac{\text { Hispanic }}{\text { Major HP }} \\
\text { Minor HP } \\
\text { No HP }\end{array}$ & $\begin{array}{r}33 \\
10 \\
0\end{array}$ & $\begin{array}{l}77 \% \\
23 \\
0\end{array}$ & $\begin{array}{l}8 \\
4 \\
1\end{array}$ & $\begin{array}{l}61 \% \\
31 \\
8\end{array}$ & $\begin{array}{l}7 \\
2 \\
0\end{array}$ & $\begin{array}{l}78 \% \\
22 \\
0\end{array}$ \\
\hline $\begin{array}{l}\text { Native Am } \\
\text { Major HP } \\
\text { Minor HP } \\
\text { No HP }\end{array}$ & $\begin{array}{l}0 \\
2 \\
0\end{array}$ & $\begin{array}{c}0 \% \\
100 \\
0\end{array}$ & $\begin{array}{l}0 \\
0 \\
0\end{array}$ & $\begin{array}{l}0 \% \\
0 \\
0\end{array}$ & $\begin{array}{l}0 \\
0 \\
0\end{array}$ & $\begin{array}{l}0 \% \\
0 \\
0\end{array}$ \\
\hline $\begin{array}{l}\frac{\text { White }}{\text { Major HP }} \\
\text { Minor HP } \\
\text { No HP }\end{array}$ & $\begin{array}{r}24 \\
7 \\
0\end{array}$ & $\begin{array}{l}77 \% \\
23 \\
0\end{array}$ & $\begin{array}{r}14 \\
7 \\
0\end{array}$ & $\begin{array}{c}67 \% \\
33 \\
0\end{array}$ & $\begin{array}{l}8 \\
3 \\
1\end{array}$ & $\begin{array}{l}67 \% \\
25 \\
8\end{array}$ \\
\hline
\end{tabular}

Note. 347 valid questionnaires minus 157 with no indication of history of HBP, Stroke, or HT D $=\underline{N}$ of 190 . 
pressure, stroke, or heart disease, versus no answer to the question could not be determined. Therefore, those questionnaires could not be analyzed for inclusion in Table 2 and Table 3 . Answers from the remaining questionnaires showed more family members with high blood pressure $(\underline{\underline{n}}=120)$ than stroke $(\underline{n}=43)$ or heart disease $(\underline{n}=27)$. In Table 2 , $70 \%$ to $78 \%$ of the individuals with family members who have or have had high blood pressure, stroke, or heart disease, responded to the questionnaire with an awareness that high blood pressure is a major health problem. Table 3 shows the level of awareness of students from various ethnic groups of high blood pressure as a health problem, who have or have had a family member with either high blood pressure, stroke, or heart disease. In 4 of the 5 ethnic groups, the majority ( $61 \%$ to $100 \%$ ) of respondents to the questionnaire, indicated they were openly aware that high blood pressure is a major health problem. The highest percentage for individuals who were aware that high blood pressure is a major health problem was from the Black ethnic group with $90 \%$ to $100 \%$. This finding is not surprising as the California Department of Health Services in their comparison study from 1969-71 and 1979-81 also found that Blacks have the highest hypertension-related mortality, followed by Whites. Asians showed low rates of hypertension-related mortality (Stavig, Igra, Leonard, McCullough, \& Oreglia, 1986). 


\section{Chapter 5}

\section{CONCLUSIONS AND RECOMMENDATIONS}

\section{Conclusion}

The total percentage for Table 1 for all ethnic groups of students was $79 \%(\underline{n}=274)$ for open awareness of high blood pressure as a major health problem. Sixteen percent $(\underline{n}=57)$ were in the suspicion awareness category. These individuals were not certain if high blood pressure is a major health problem, and therefore indicated on the questionnaire that it is a minor one. Five percent ( =16) were in the closed awareness category who were not aware of the medical consequences of high blood pressure, and therefore indicated on the questionnaire that it is not a health problem.

Table 2 shows the percentage, $63 \%(n=120)$, for all ethnic groups who have family members with a history of high blood pressure. This tally is calculated from the figures in Table 3 which show the percentage for each of the five ethnic groups. Seventy-seven percent ( $\underline{n}=$ 92) of the individuals from the five ethnic groups were openly aware of high blood pressure as a major health problem. Twenty-one percent $(\underline{n}=25)$ were in the suspicion awareness category. These individuals were not certain if high blood pressure is a major health problem, and therefore indicated on the questionnaire that it is a 
minor one. Two percent $(\underline{\underline{n}}=3)$ were in the closed awareness category who were not aware of the medical consequences of high blood pressure and therefore indicated it is not a health problem.

Table 2 shows the percentage, $23 \%(n=43)$, for all ethnic groups who have family members with a history of stroke. Seventy percent $(\underline{n}=30)$ of the students were openly aware that high blood pressure is a major health problem. Twenty-eight percent $(\underline{\underline{n}}=12)$ were in the suspicion awareness category. These individuals were not certain if high blood pressure is a major health problem and therefore indicated on the questionnaire that it is a minor one. Two percent $(\underline{n}=1)$ were in the closed awareness category who were not aware of the medical consequences of high blood pressure and therefore indicated on the questionnaire that it is not a health problem.

Table 2 shows the percentage, $14 \%(n=27)$, for all ethnic groups who have family members with a history of heart disease. Seventy-eight percent $(\underline{n}=21)$ of the students were openly aware of high blood pressure as a major health problem. Eighteen percent $(\underline{n}=5)$ were in the suspicion awareness category. These individuals were not certain if high blood pressure is a major health problem and therefore indicated on the questionnaire that it is a minor one. Four percent $(\underline{n}=1)$ were in the closed 
awareness category who were not aware of the medical consequences of high blood pressure and therefore indicated on the questionnaire that it is not a health problem.

Since the racial differences associated with

persistent hypertension do not appear until late adolescence (Fixler, Laird, Fitzgerald, Stead, \& Adams, 1979), and "the greater tendency to hypertension in black adults does not appear during the first two decades of life" (Goldring et al., 1977, p. 888), awareness of the dangers of high blood pressure if taught in childhood and adolescence may lessen or prevent the effects of high blood pressure in adulthood. Students who follow in the same path of risk factors as their family member who has the disease, also have the potential to acquire it.

\section{Recommendations}

1. High blood pressure education programs should be incorporated into all the elementary and high school health classes.

2. More high school students should be trained as American Heart Association blood pressure screeners. This would increase the high school students' awareness of high blood pressure as a major health problem.

3. Long term blood pressure studies in childhood and adolescence should be started. These studies may help us determine the age that high blood pressure begins 
in those who are in the high risk groups. The studies should be focused on individuals who have family members with a history of hypertension and those who are of the Black ethnic group.

4. Studies should be done which can determine in what manner the students receive the most education about high blood pressure as a major health problem so that enforcement of that form can be implemented. 
REFERENCES 


\section{References}

American Heart Association. (1982). Putting your heart into the curriculum (Publication No. 95-020-D). Dallas, TX: National Center.

American Heart Association. (1985). Fact sheet on heart attack, stroke and risk factors (Publication No. 51-024-J). Dallas, TX: National Center. American Heart Association. (1987). Heart facts (Publication No. 55-005-K). Dallas, TX: National Center. American Heart Association. (1988). Heart facts

(Publication No. 55-0351). Dallas, TX: National Center. American Heart Association. (1989). Fact sheet on heart attack, stroke and risk factors (Publication No. 51-1011). Dallas TX: National Center. Baron, A. E., Freyer, B. \& Fixler, D. E. (1986). Longitudinal blood pressures in Blacks, Whites, and Mexican Americans during adolescence and early adulthood. American Journal of Epidemiology, 123, 809-817.

Burke, G. L., Freedman, D. S., Webber, L. S., \& Berenson, G. S. (1986). Persistence of high diastolic blood pressure in thin children. Hypertension, 8 , 24-29. Burns. T. L., \& Lauer, R. M. (1987). Blood pressure in children. In M. E. Mascia Pierpont \& J. H. Moller (Eds.), The genetics of cardiovascular disease (pp. 305-317). Boston: Martinus Nijhoff. 
Dannenberg, A. L., Drizd, T., Horan, M. J., Haynes, S. G., \& Leaverton, P. E. (1987). Progress in the battle against hypertension. Hypertension, 10, 226-233.

Dorsett, J. D., Jr., Woods, J. W., White, K. L., Smith, H. Jr., \& Hill, R. (1958). An evaluation of drug therapy in hypertension. Journal of Chronic Diseases, I, 287-299. Dustan, H. P. (Ed.). (1982). 1982: A critical year for hypertension. Hypertension, $4,1-2$.

Falkner, B. (1986). Management of hypertension in children and adolescents. American Family Physician, $34(5)$, 101-109.

Fixler, D. E., \& Laird, W. P. (1983). Validity of mass

blood pressure screening in children. Pediatrics, $\underline{72}$, 459-463.

Fixler, D. E., Laird, W. P., Fitzgerald, V., Stead, S., \& Adams, R. (1979). Hypertension screening in schools: Results of the Dallas study. Pediatrics, 63, 32-36. Freis, E. D. (1958). Rationale and methods for the treatment of ear1y essential hypertension. Journal of the National Medical Association, 50, 406-412. Glaser, B. G., \& Strauss, A. L. (1964). Awareness contexts and social interaction. American Sociological Review, 29, $669-679$.

Glaser, B. G., \& Strauss, A. L. (1965). Awareness of dying. Chicago: Aldine. 
Goldring, D., Londe, S., Sivakoff, M., Hernandez A., Britton, C., \& Choi, S. (1977). Blood pressure in a high school population. The Journal of Pediatrics, $\underline{91}, 884-889$.

Horan, M. J. \& Sinaiko, A. R. (1987). Synopsis of the report of the second Task Force on Blood Pressure Control in Children. Hypertension, 10, 115-121. Joint National Committee on Detection, Evaluation, and Treatment of High Blood Pressure. (1977). Report of the Joint National Committee on Detection, Evaluation, and Treatment of High Blood Pressure. The Journal of the American Medical Association, 237, 255-261.

Joint National Committee on Detection, Evaluation, and Treatment of High Blood Pressure. (1980). The 1980 report of the Joint National Committee on Detection, Evaluation, and Treatment of High Blood Pressure. Archives of Internal Medicine, 140, 1280-1285.

Joint National Committee on Detection, Evaluation, and Treatment of High Blood Pressure. (1984). The 1984 report of the Joint National Committee on Detection, Evaluation, and Treatment of High Blood Pressure. Archives of Internal Medicine, 144, 1045-1057. 
Joint National Committee on Detection, Evaluation, and Treatment of High Blood Pressure. (1988). The 1988 report of the Joint National Committee on Detection, Evaluation, and Treatment of High Blood Pressure. Archives of Interna1 Medicine, 148 , 1023-1038.

Klatzky, R. L. (1984). An introduction to memory and awareness. In R. L. Klatzky (Ed.), Memory and awareness: An information processing perspective (pp. 1-14). New York: W. H. Freeman.

Lee, R. E., Seligmann, A. M., Goebel, D., Fulton, L. A., \& Clark, M. A. (1956). Reserpine-hydralazine combination therapy of hypertensive disease, with hydralazine in doses generally below the "toxic range". Annals of Internal Medicine, 44, 456-465.

Lewis, I. (1980). Hypertension treatment compliance: A study on Blacks and minorities. The Western Journal of B1ack Studies, 4 , 33-39.

Loggie, J. M. H., Horan, M. J., Hohn, A. R., Gruskin, A. B., Dunbar, J. B., \& Havlik, R. J. (1984). Juvenile hypertension: Highlights of a workshop. The Journal of Pediatrics, 104, 657-663.

Londe, S., Gollub, S. W., \& Goldring, D. (1977). Blood pressure in Black and in White children. The Journal of Pediatrics, 90, 93-95. 
Lynds, B. G., Seyler, S. K., \& Morgan, B. M. (1980). The relationship between elevated blood pressure and obesity in Black children. American Journal of Public Health, 70, $171-173$.

Mollohan, C. J. (1986). Hypertension programs in schools. The Journal of School Health, 56, 237-239. Polit, D. F., \& Hungler, B. P. (1983). Nursing research (2nd ed.). Philadelphia, PA: J. B. Lippincott. Prineas, R. J., \& Gillum, R. (1985). U. S. epidemiology of hypertension in Blacks. In W. D. Hall, E. Saunders, \& N. B. Shulman (Eds.), Hypertension in Blacks (pp 17-36). Chicago: Year Book Medical. Rames, L. K., Clarke, W. R., Connor, W. E., Reiter, M. A., \& Lauer, R. M. (1978). Normal blood pressures and the elevation of sustained blood pressure elevation in childhood: The Muscatine study. Pediatrics, 61, 245-251. Shear, C. L., Freedman, D. S., Burke, G. L., Harsha, D.

W., \& Berenson, G. S. (1987). Body fat patterning and blood pressure in children and young adults. Hypertension, 9, 236-244.

Sinaiko, A. R., Gomez-Marin, 0., \& Prineas, R. J. (1989). Prevalence of "significant" hypertension in junior high school-aged children: The children and adolescent blood pressure program. The Journal of Pediatrics, 114, $664-669$. 
Stamler, J. (1973). High blood pressure in the United States-An overview of the problem and the challenge. In National Heart and Lung Institute (Ed.), National Conference on High Blood Pressure Education (DHEW Publication No. 73-486, pp. 11-57). Bethesda, MD: National Institute of Health. Stamler, J., Stamler, R., Riedlinger, W. F., Algera, G., \& Roberts, R. H. (1976). Hypertension screening of 1 million Americans. The Journal of the American Medical Association, 235, 2299-2306. Stamler, R., Stamler, J., Riedlinger, W. F., Algera, G., \& Roberts, R. H. (1979). Family (parental) history and prevalence of hypertension. The Journal of the American Medical Association, 241, 43-46.

Stavig, G. R., Igra, A., Leonard, A- R., McCullough, J., \& Oreglia, A. (1986). Hypertension-related mortality in California. Public Health Reports, 101, $39-49$.

Task Force Members. (1977). Report of the Task Force on Blood Pressure Control in Children. Pediatrics, 59, 796-820.

Task Force Members. (1987). Report of the second Task Force on Blood Pressure Control in Children-1987. Pediatrics, $\underline{79}, 1-25$. 
Tochikubo, 0., Sasaki, 0., Umemura, S., \& Kaneko, Y. (1986). Management of hypertension in high school students by using new salt titrator tape. Hypertension, 8, $1164-1171$.

Veterans Administration Cooperative Study Group. (1960). A double blind control study of antihypertensive agents [Report No. 1]. Archives of Internal Medicine, 106, 81-96. Veterans Administration Cooperative Study Group. (1962). Double blind control study of antihypertensive agents [Report No. 2]. Archives of Internal Medicine, 110, 222-229.

Veterans Administration Cooperative Study Group. (1962). Double blind control study of antihypertensive agents [Report No. 3]. Archives of Internal Medicine, 110, 230-236.

Veterans Administration Cooperative Study Group. (1967). Effects of treatment on morbidity in hypertension. The Journal of the American Medical Association, 202, 1028-1034.

Veterans Administration Cooperative Study Group. (1970).

Effects of treatment on morbidity in hypertension. The Journal of the American Medical Association, 213, 1143-1152.

World Health Organization Expert Committee. (1978). Arterial hypertension (WHO Tech. Rep. No. 628). Geneva: WHO. 
World Health Organization Study Group. (1985). Blood pressure studies in children (WHO Tech. Rep. No. 715). Geneva: WHO. 
APPENDIX A

Blood Pressure Standards for Children 

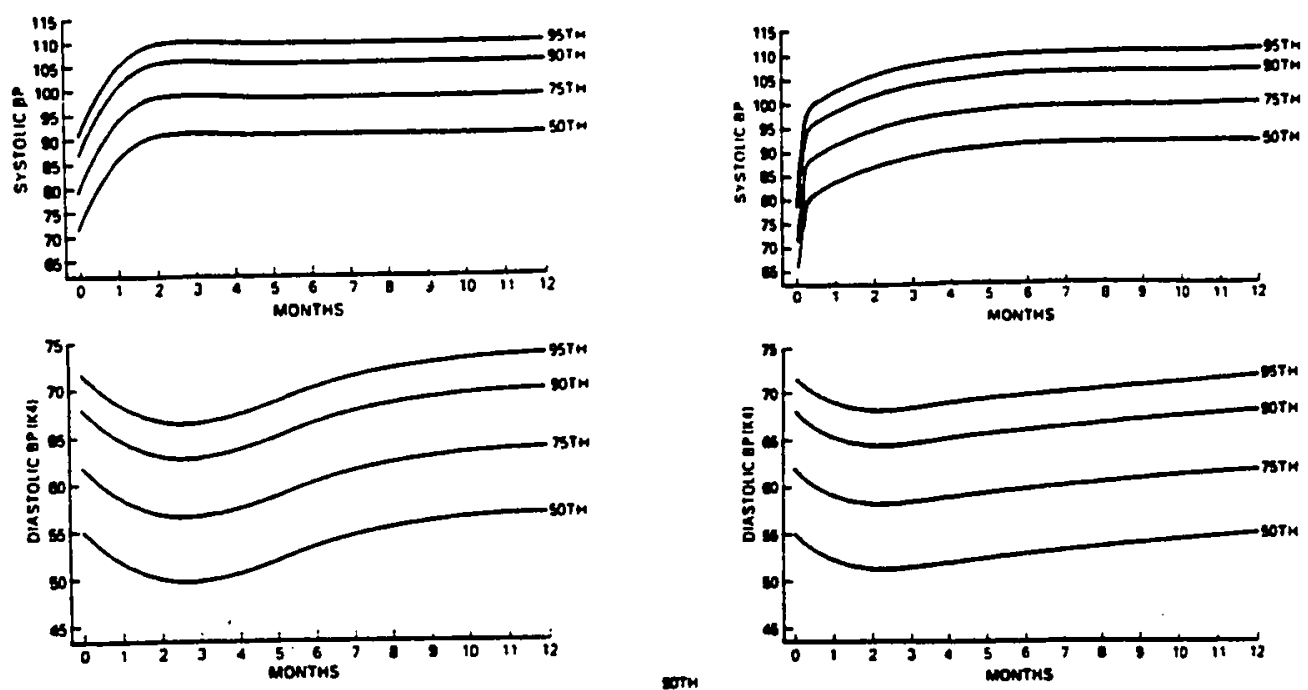

Pencentu.

SYSTOLIC

Dinstoric

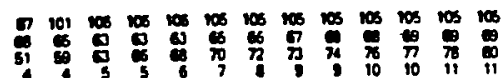

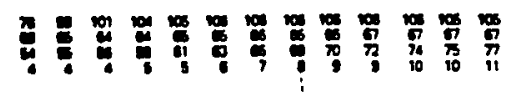

Figure 3. Age-specific

Figure 4. Age-specific

percentiles of $\mathrm{BP}$

percentiles of $B P$

measurements in boys-

measurements in girls-

birth to 12 months of age;

birth to 12 months of age;

Korotkoff phase IV (K4)

Korotkoff phase IV (K4)

used for diastolic BP.

used for diastolic BP.

Note. From "Report of the Second Task Force on Blood Pressure Control in Children-1987" by Task Force Members, 1987, Pediatrics, 79, p. 5. Copyright 1987 by Pediatrics. Reproduced by permission of Pediatrics. 

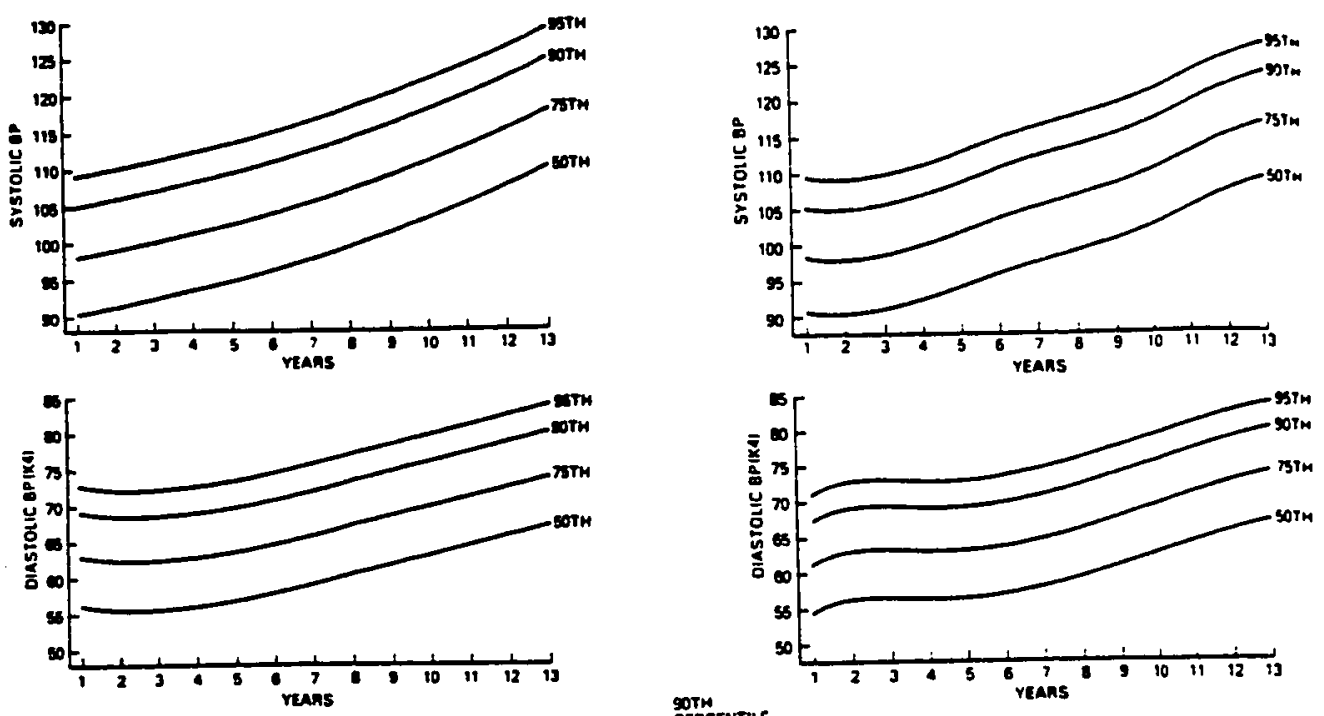

Figure 5. Age-specific

Figure 6. Age-specific

percentiles of $B P$

percentiles of $\mathrm{BP}$

measurements in boys-

measurements in girls-

1 to 13 years of age;

1 to 13 years of age;

Korotkoff phase IV (K4)

Korotkoff phase IV (K4)

used for diastolic BP.

used for diastolic BP.

Note. From "Report of the Second Task Force on Blood Pressure Control in Children-1987" by Task Force Members, 1987, Pediatrics, $\underline{79}$, p. 5. Copyright 1987 by Pediatrics. Reproduced by permission of Pediatrics. 
APPENDIX B

Questionnaire 


\section{AMERICAH MEART ASSOCIATIOH \\ SAKTA CLARA COUKTY GIAPTER \\ 3003 Koorpart Avenue, San Jose, Callfornta 95123}

THIS IMFORMATIOH IS COMFIOEMTIAL: Do HOT write your name on thls paper. Th1s informi wilt help determine how auch high blood pressure oec in your age group.

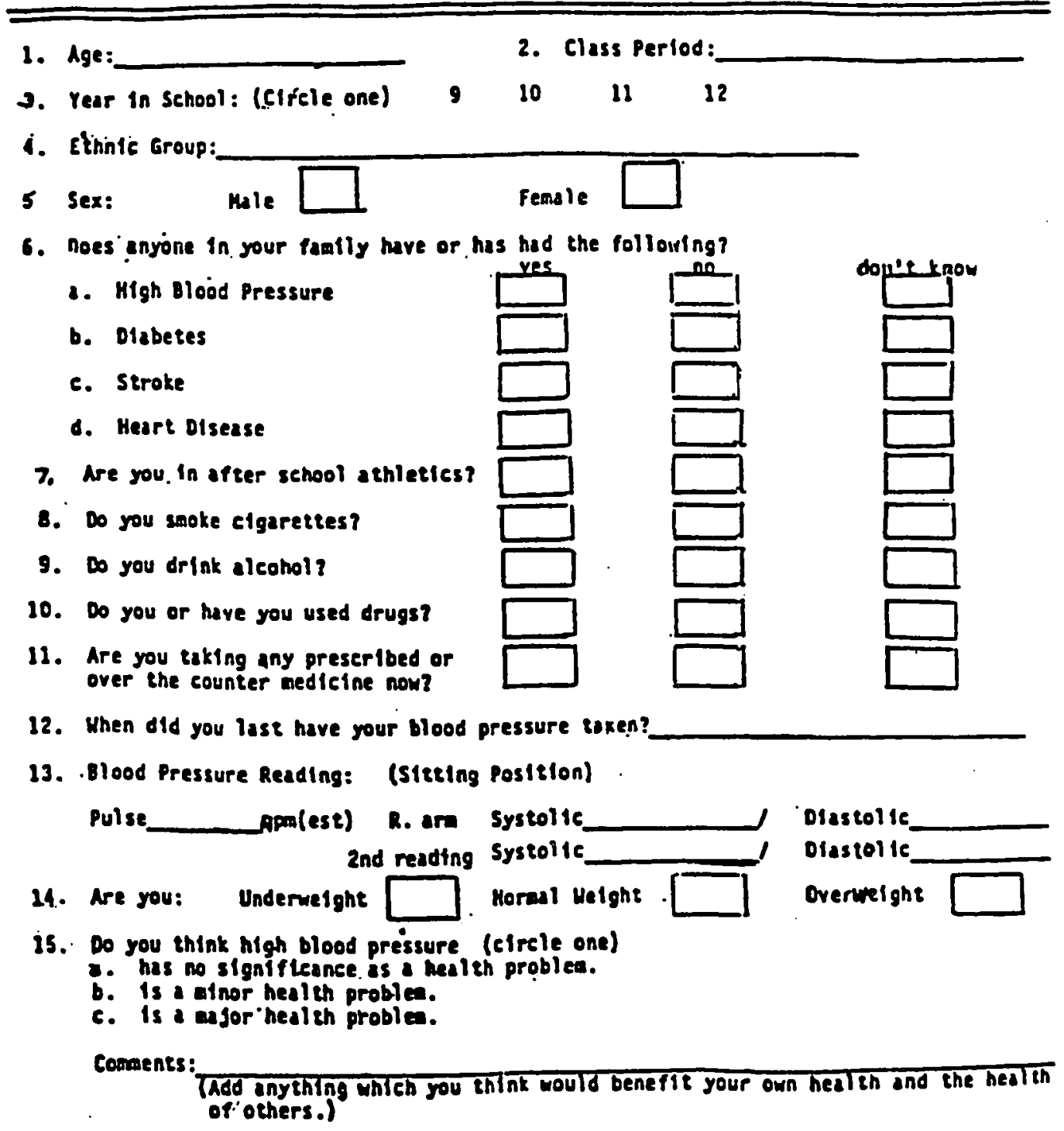
QATE: 1982 
APPENDIX C

Consent Letter 
SANTA CLARA COUNTY CHAPTER 3003 Moorpark Avenue, Son Jose, California 95128 cooperating in Business and Industry with United Wov.

WE'RE FIGHTING FOR YOUR LIFE

April 23, 1986

Carol Sadlier

18847 Casa Blanca Lane

Saratoga, California 95070

Dear Carol,

Thank you for your letter of April 1, 1986 regarding the use of the High School Blood Pressure Questionaire in your thes is. These questionaires were a part of the American Heart Association schoolsite program that you participated in, in the capacity of instruction as an intern from San Jose State University.

You are welcome to use the information so long as you do not use names of individuals or, as you mentioned, the name of the school.

Good luck with your thes is and once again, thank you for the excellent contribution you made to our schoolsite program.

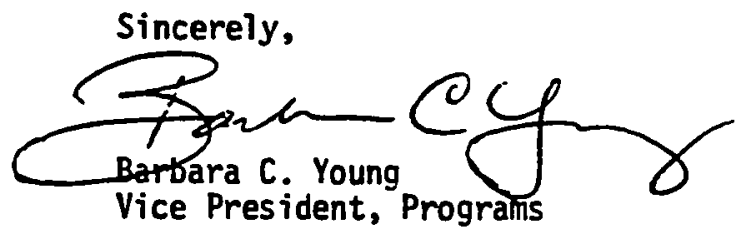

BCY:ap 
APPENDIX D

Committee for the Protection of Human Subjects 


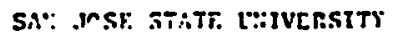 \\ C.AnT:AT: STIDLT.S A::! REST.ARCII \\ Committee for the Protectlon of lltuan Subjects \\ Project Proposal Review
}

Wc, the undersigned members of the San Jose State University Committee for the

Protection of Hums Subjects, have revieved the following proposal subsitted to the Comaitzee on May 12, 1986 by :

Principal Investigator Carol Sachier

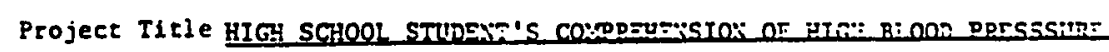

AS A MAJOR HEAITH PROBIE: IZ OZZ SOCTETY

We recomend the following action (indicate one):

2. Approved for clearance as involving vinimal risk to husan subjects.

2. Approved for clearance with rist: to human subjects.

3. Approved for clearance when the following conditions are wer:

4. Return to principal Investigator for following reasons:

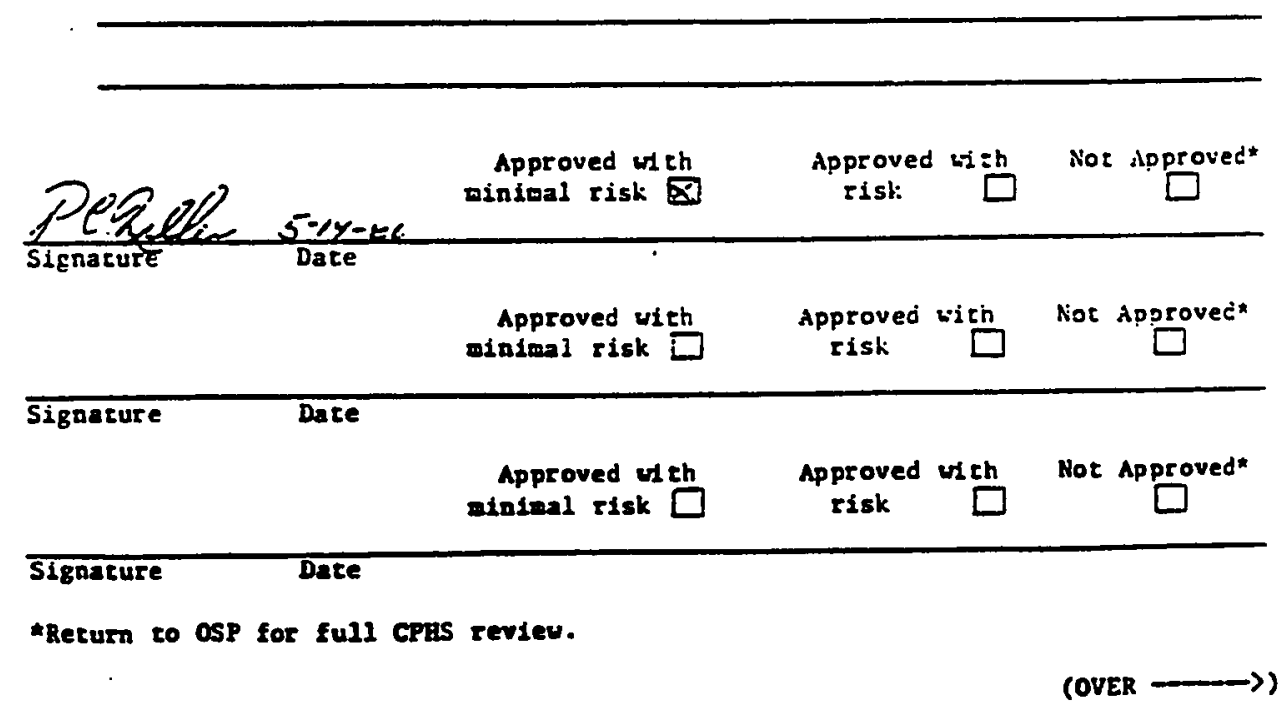




\begin{tabular}{|c|c|c|c|c|}
\hline & & $\begin{array}{l}\text { Approved with } \\
\text { minimal risk } \square\end{array}$ & $\begin{array}{l}\text { Approved with } \\
\text { risk }\end{array}$ & Not Approved \\
\hline \multirow{2}{*}{ SIgnature } & Date & & & \\
\hline & & $\begin{array}{l}\text { Approved with } \\
\text { mininal rist: }\end{array}$ & $\begin{array}{c}\text { Approved with } \\
\text { risk }\end{array}$ & Not Approved* \\
\hline \multirow[t]{2}{*}{ Signacure } & Date & & & \\
\hline & & $\begin{array}{l}\text { Approved with } \\
\text { mini=al sisk: }\end{array}$ & $\begin{array}{c}\text { Approved with } \\
\text { risk }\end{array}$ & Not Apnroved* \\
\hline
\end{tabular}

Signature Date

•

*Return to OSP for full CPHS revies.

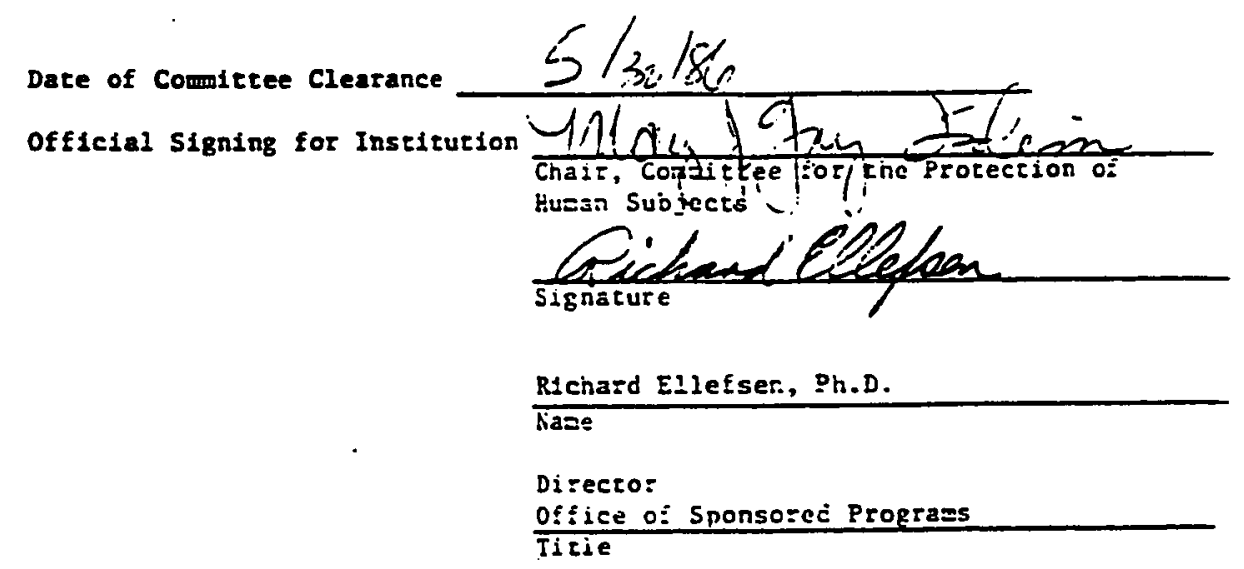

San Jose Stace University

125 Souch Sevench Street

San Jose, Callfornia 95192

(408) 277-2941 